\title{
Study of the effect of composition of various food flours on the quality of developed biscuits
}

\section{Rajmani Prajapati*, Suresh Chandra and Samsher}

Department of Agricultural Engineering

S.V. P. University of Agriculture \& Technology, Meerut - 250110 (U.P.)

*Email: chandra21778@yahoo.co.in

\begin{abstract}
The present investigation was carried out to study the effect of different flour composition on the quality of biscuits. Experiments were conducted to develop the mixed flours. Wheat flour was incorporated with mushroom flour, black gram flour, soya flour and jowar (sorghum) flour blends in ratios of 100:0:0:0:0, $90: 2.5: 2.5: 2.5: 2.5,80: 5.0: 5.0: 5.0: 5.0$ and 70:7.5:7.5:7.5:7.5, respectively. Wheat flour of the ratio of 100:0:0:0:0 was considered as control. The biscuits were developed from the different levels of mixed flour. In this connection, to evaluate their physico-chemical properties such as ash content, moisture content and protein increased with increasing the level of mixed flour in biscuits. Prepared biscuits were packaged in HDPE stored at room temperature upto 90 days and to examine overall sensory quality attributes of biscuits. From present investigation, it was concluded that $5 \%$ mixed flour based biscuits were found to be better organoleptically than those of other ratios and followed by the ratio of $2.5 \%, 7.5 \%$ and wheat flour biscuits, packaged in HDPE, respectively.
\end{abstract}

Keywords: composite flour, biscuits, protein, overall sensory quality.

Paper cited: Prajapati, R., Chandra, S. and Samsher (2019). Study of the effect of composition of various food flours on the quality of developed biscuits. South Asian Journal of Food Technology and Environment, 5(1): 771-777.

\section{Introduction}

Biscuits are a most popular bakery food products consumed by a wide range of population due to their ready to eat nature, good nutritional quality, wide range of varieties, affordable cost, long shelf life, easy to availability (Laguna et al., 2011). The biscuit industry is the largest constituent of food processing industry. In India the organized sector produces around $60 \%$ of the total production and the remaining $40 \%$ being contributed by the unorganized bakeries. The industry consists of two large scale manufacturers, around 60 medium scale brands and small scale units ranging up to 4500 units in the country. The unorganized sector is estimated to have approximately 30,000 small \& tiny bakeries across in the country. There is a great scope for biscuit industry in India as the demand for biscuit is increasing $7 \%$ per annum which may increase further with globalization of economy and urbanization, but annual production growth rate is approximately $2-4 \%$ per annum. Though India is considered as the third largest producer of biscuits after USA and China, the export of biscuits is approximately $17-20 \%$ of the total annual production. The per capita consumption of biscuits in our country is only $2.1 \mathrm{Kg} /$ year.

Therefore, it has become imperative to develop cultivars for biscuit. The quality of the flour for biscuit making depends on the texture and composition of the kernel. Soft texture of grain, low protein content and weak gluten strength are primary requirements of biscuit making quality. Protein deficiency is one of the important dietary problems in many of the developing countries. Although animal products are the most desirable protein sources, their limited availability and high cost restrict their 
use in poor people. Consequently there has been a large and growing need of high quality and low cost plant proteins. Mixture of high protein cereal like corn, legumes such as soybean and green gram for the production of highly nutritious biscuits, snacks etc. (Mishra et al., 1991).

The addition of legume to cereal-based products could be a good alternative for increasing the intake of legumes. In addition, legume proteins are rich in lysine and deficient in sulphur containing amino acids, whereas cereal proteins are deficient in lysine, but have adequate amounts of sulphur amino acids (Eggum and Beame, 1983). Cereal grains like wheat, corn, rice, barley, sorghum, etc. provide $68 \%$ of the total world food supplies. Wheat is mainly used as a dietary staple, averaging twothirds of total consumption (Anjum et al., 2005).

Senthil et al., (2002) studied on the quality of fried snacks based on blends of wheat flour and defatted soya flour in the ratio of $65: 20,60: 25,55: 30$ and 45:40 in respect of dough characteristics and quality of fried savoury and sweet snacks prepared from them. Farinograph characteristics of flour blends showed that as the proportion of soya flour increased there was a slight increase in water absorption and decrease in dough stability. In fried savoury snacks the protein content increased gradually from 20.75 to $27.50 \%$. When the proportion of soya flour was raised from 20 to $40 \%$ in the blend, the corresponding rise in protein content in fried sweet snack was from 15.75 to $21.75 \%$. Chandra et al., (2015) worked on the development biscuits from the composite flours incorporating wheat flour with rice, green gram and potato flour. Composite flours were prepared by blending wheat flour with rice flour, mung flour and potato flour in ratios of 100:0:0:0 $\left(\mathrm{W}_{100}\right)$, 85:5:5:5 $\left(\mathrm{W}_{85}\right)$, 70:10:10:10 $\left(\mathrm{W}_{70}\right)$ and 55:15:15:15 $\left(\mathrm{W}_{55}\right)$, respectively. The protein, fat, ash and $\mathrm{pH}$ increased with increasing proportion of rice, green gram and potato flour from 5 to 15 percent while acidity was decreased simultaneously. In case of individual flour, wheat flour was found highest moisture (13.284\%), green gram for protein $(21.038 \%)$ and fat $(1.226 \%)$ and potato for ash content $(1.092 \%)$. The biscuits were prepared from wheat flour $\left(\mathrm{W}_{100}\right)$ and three composite flours $\left(\mathrm{W}_{85}, \mathrm{~W}_{70}\right.$, and $\left.\mathrm{W}_{55}\right)$. The physical properties of these biscuits were observed. The mass, diameter, thickness and bulk densities decreased whereas spread ratio and percent spread increased with increasing the level of incorporation of other flours.

\section{Materials and Methods}

Raw materials viz., Wheat flour (maida), Mushroom flour, Blackgram flour, Soya flour and jowar flour and Chemicals and other desired materials etc were procured from local market of Meerut (UP) India for the present study. The entire studies were conducted in the Department of Agricultural Engineering and Food Technology, S.V.P. University of Agric. \& Tech., Meerut (U. P.). Instruments / equipment used were knife, trays, grinder, whiley mill, sieve, electronic balance, hot air oven, centrifuge, desiccator, water bath, test tube and measuring cylinder etc. Composite flour was made from refined wheat flour, mushroom flour, black gram flour, full fat soya flour and jowar (sorghum) flour. Detailed methodology of Biscuit development is given below.

Biscuit development: Biscuits were prepared from composite flour incorporating wheat flour, mushroom flour, black gram flour, soya flour and jowar (sorghum) flour blends in ratios of 100:0:0:0:0, 90:2.5:2.5:2.5:2.5, 80:5.0:5.0:5.0:5.0 and 70:7.5:7.5:7.5:7.5, respectively. Wheat flour biscuit of the ratio of 100:0:0:0:0 were considered as control. The standardized formulation for biscuit had ingredients as $100 \mathrm{~g}$ flour, $60 \mathrm{~g}$ sugar, $50 \mathrm{~g}$ hydrogenated fat, $1.25 \mathrm{~g}$ sodium bicarbonate, $1.25 \mathrm{~g}$ baking powder and $1.0 \mathrm{~g}$ sodium chloride salt. Hot liquid hydrogenated fat and sugar were taken and creamed to a uniform consistency. The flour, required $20-22 \%$ of water, baking powder and sodium bicarbonate were added to creamed mixture and mixed for $10 \mathrm{~min}$ at medium speed in dough mixer to obtain a homogeneous mixture. The dough was rolled out into thin sheet of uniform thickness and was cut into desired shape using mould. The cut pieces were placed over perforated tray and transferred into baking oven at $180^{\circ} \mathrm{C}$ for $10-15 \mathrm{~min}$ till baked. The well baked biscuits were removed from the oven, cooled to room temperature, 
Study of the effect of composition of various food flours on the quality of developed biscuits

packaged and stored in air tight container till further use and study. Biscuits made from composite flour were immediately filled in packaging materials viz. High density polyethylene (HDPE).

\section{Physico-chemical quality of Biscuits}

Moisture content (M.C.): Initial moisture content of samples was determined by hot air oven drying method as recommended by Ranganna (2001). The moisture content tests were carried out in triplicate and weighing was done to the nearest $\pm 1 \mathrm{mg}$. The moisture content of sample was calculated using following equation.

$$
M C, \%=\frac{M_{1}-M_{2}}{M_{0}} \times 100
$$

Where,

$$
\begin{aligned}
& \mathrm{MC}=\text { Moisture content of } \\
& \text { sample, \% (w.b.) } \\
& \mathrm{M}_{0}=\text { Initial weight of sample } \\
& \text { taken, } 5 \mathrm{~g} \\
& \text { dish with cover before oven drying cover, } g \\
& \mathrm{M}_{2}=\text { Weight of dried sample } \\
& \text { and dish with cover after oven drying, } \mathrm{g} \text {. }
\end{aligned}
$$

pH Content: The $\mathrm{pH}$ of the biscuit samples was determined as described by Egan et al., (1981) for flours. $10 \mathrm{~g}$ of each sample was suspended in $90 \mathrm{ml}$ sterile distilled water and homogenized. The mixtures were allowed to stand for $30 \mathrm{~min}$ before being filtered. The electronic $\mathrm{pH}$ meter was calibrated using $7 \mathrm{pH}$ and $4 \mathrm{pH}$ standard buffer solutions. The $\mathrm{pH}$ values of the filtrates were then determined by a combined glass electrode probe and a $\mathrm{pH}$ meter (Systronics $\mu$ $\mathrm{pH}$ system-361). Three readings were taken per sample. $\mathrm{pH}$ is the measurement of the logarithm of inverse of hydrogen ions in the solution.

$$
\mathrm{pH}=-\log \left(\mathrm{H}^{+}\right)
$$

(g/lit)

Where, $\mathrm{H}^{+}=$hydrogen ion concentration
Acidity: Acidity of various samples was determined by using the method as recommended by Ranganna (2001). Five gram sample flour or biscuits was dissolved in a $50 \mathrm{ml}$ of distilled water and out of this $20 \mathrm{ml}$ aliquot was taken and titrated with $0.1 \mathrm{~N} \mathrm{NaOH}$ using a few drops of phenolphthalein solution as indicator. The end point was judged by the appearance of pink colour. The titer value was noted and result was calculated as per cent total acids using following equation.

$\%$ Titrable Acidity $-\frac{\mathrm{ml} \mathrm{NaOH} \times \mathrm{N} \mathrm{NaOH} \times \text { Meq. weight of acid } \times 100}{\mathrm{~mL} \text { sample titrated }}$

Optical density: Optical density is the measurement of light that is absorbed by any material when a beam of light falls on it. According to Bear's law the intensity of a beam of monochromatic light decreases exponentially as concentration of absorbing substance increases.

Mathematically, O.D. of medium is given by following formula.

$$
\text { Optical Density }=\log \frac{I_{o}}{I_{t}}
$$

Where,

$1_{0}=$ Intensity of the incident light

$1_{t}=$ Intensity of light transmitted

through the medium.

Optical density of biscuits was determined by the method as recommended by Ranganna (2001). $5 \mathrm{~g}$ of sample was taken and mixed well in $100 \mathrm{ml}$ of $60 \%$ alcohol, kept for 12 hours in a refrigerator and filtered using Whattman No. 1 filter paper. The spectrophotometer (Elico SLI71) was calibrated by inserting cuvette filled with blank $(60 \%$ alcohol) and calibration knob was adjusted to 0 value at $440 \mathrm{~nm}$ wavelength. Filterate was then inserted similarly and reading was recorded. Browning index was expressed in terms of optical density (O.D.). 
Protein content : In this method, protein was analytically estimated by determining the amount of total nitrogen in the samples by KjelDhal method as recommended by Ranganna (2001).

$\%$ Nitrogen $=\frac{\text { (Sample titre-blank titre) } \times \mathrm{nHCl} \times 14 \times \text { Volume made up of digest } \times 100}{\text { Aliquot of digest taken } \mathrm{x} \text { weight of sample taken } \times 1000}$

Protein $\%=$ Nitrogen $(\%) \times 6.25^{*}$

Ash content (\%): Ash content was determined by the method as recommended by BIS (1977), standard methods for the examination of flours and biscuits. In a clean silica dish, $5 \mathrm{~g}$ of homogenous sample of flour or biscuits was weighed and $6 \mathrm{ml}$ of nitric acid was added and heated at low fire until the changing of colour was completed. Thereafter, silica dish was transferred to an electric furnace maintained at a temperature of about $850 \pm 20^{\circ} \mathrm{C}$ and ignite till carbon free. The dish was cooled down in desiccators and weighed. The process was repeated till constant weight was obtained.

$$
\operatorname{Ash}(\%)=\frac{W_{2}-W_{1}}{W} \times 100
$$

Where,

$\operatorname{ash}(\mathrm{g})$.

$$
\begin{array}{lll}
\mathrm{W} & = & \text { weight of sample, }(\mathrm{g}) \\
\mathrm{W}_{1} & = & \text { weight of silica dish }(\mathrm{g}) \\
\mathrm{W}_{2} & = & \text { weight of silica dish }+
\end{array}
$$

Sensory qualities evaluation: Sensory quality attributes viz. Color, texture, flavor, taste and overall acceptability of the samples were evaluated. Nine points Hedonic rating test method as recommended by Ranganna (2001) was used for the purpose of sensory evaluation. This test measures the consumer's acceptability. A semi trained panel consisting of both gender more than 10 judges of different age groups having different eating habits were constituted to evaluate the quality. The judges were selected from the faculty staff and students of Department of Agricultural Engineering, SVPUA\&T, Meerut (U. P.). The judgments were quantified by appropriate analysis for determining the significance of variation of average scores and the contribution of the individual quality characteristics to the overall quality. Samples were served to the panelists and they were asked to rate the acceptability of the product through sense of organs. Different attributes viz. color, texture, flavor and taste were rated on the basis of 9- point hedonic scale ranging from 1 (extremely dislike) to 9 (extremely like).

\section{Results and Discussion}

The biscuits was developed and stored at room temperature after packaging in, HDPE for three months. The physico-chemical as well as sensory properties of biscuits was also evaluated as a fresh and during storage of 30, 60 and 90 days intervals. The range of levels of flours and different parameters were selected on the basis of literature for biscuits.

Moisture content: The moisture content of $7.5 \%$ mixed flour based biscuits showed highest value of $2.923 \%$ in comparison control biscuits which had lowest value $(2.703 \%)$. The moisture contents of biscuits with different flour composition are shown in Table 1. The moisture content of mixed flour based biscuits increased with increase the level of mixed flour. Similar effect was observed by Alim and Shams-UdDin (2003), where moisture content of all biscuits was higher than that of control biscuits. But statistically difference in moisture content of wheat flour based and a mixed flour biscuit was not-significant.

Ash Content: The individual wheat flour biscuits (control) showed very poor value of ash content $(1.1827 \%)$, where as $7.5 \%$ mixed flour based biscuits show highest value $1.9423 \%$ (Table 1). Also, $5 \%$ and $2.5 \%$ mixed flour based biscuits obtained higher value of ash content, than control biscuits. So the results are clear that ash content of mixed flour based biscuits significantly increased with increase in the level of mixed flour as shown in Table 1. Kabirullaha et al., (1995) analyzed cracker type (7 brands) biscuits and has reported the ash content in biscuits increased with increase the level of different flours.

Protein: The protein content of biscuits increased with the increased levels of different flours (Table 1). The biscuits made from $7.5 \%$ 
composite flour had highest value (7.23\%) and lowest in control biscuits (4.98\%).

Optical density: The optical density of mixed flour biscuits of $7.5 \%$ showed highest value (0.204) in comparison to other samples including control which had lowest value 0.186. From the results it is clear that as the level of mixed flour increased in biscuits, optical density of biscuits also increased. It occurred probably due to increase in protein content of biscuits. Maillard (nonenzymatice) browning occurs due to condensation reaction principally between amino acids and carbohydrates at elevated temperatures. Therefore, as the protein content increased the browning occurred more during baking. Optical density is a parameter of maillard/browning reaction of biscuits, plays a major role in colour development of biscuits. Table 1 represents the effect of flour level on the optical density of biscuits.

Acidity: The control showed a highest value of acidity (0.1856) while mixed flour biscuits of $7.5 \%$ showed the lowest value $(0.0879)$ as is evident from Table 1. It is clear from the results that as the level of mixed flour increased in biscuits from $2.5 \%$ to $7.5 \%$ the acidity decreased.

pH: The $\mathrm{pH}$ of $7.5 \%$ flour mixed biscuits indicated highest value (6.90), near to neutral, followed by $5 \%, 2.5 \%$ flour mixed and control biscuits. From Table 1, it is clear that the $\mathrm{pH}$ of biscuits increased with level of mixed flour. Acidity and $\mathrm{pH}$ are irregular reciprocal to each.

\section{Overall sensory quality of biscuits}

The overall sensory quality was evaluated for fresh as well as stored biscuits after 30, 60 and 90 days of storage. The samples were served to a group of 10 semi-trained panelists comprising male and female members of different age groups and eating habits. The various overall sensory qualities attribute estimated in form of colour, taste, mouth feel, texture on 9-point Hedonic scale concluded as overall acceptability.
The sensory data for overall acceptability of biscuits are presented in Table 2 . Results of the study revealed that the control samples were awarded overall score of 7.25 (like moderately). However biscuits prepared in the flour ratio $2.5 \%, 5 \%$ and $7.5 \%$ were rated as 7.83 (near to like very much), 8.20 (above like very much) and 7.21 (like moderately) respectively just after baking. It is, therefore, explicit that the biscuits was prepared with 5\% mixed flour biscuits awarded the maximum score of 8.20 as fresh biscuits (Table 2). Whereas, the minimum score of 6.437 (like slightly) was awarded for control biscuits, after 90 days of storage at room temperature in HDPE.

In general, decrement in overall acceptability score was observed for all the samples during storage. Control biscuits were less accepted by the more panelists' after storage of 90 days. However, biscuits sample packaged in HDPE at room temperature were acceptable after 90 days. The biscuits was developed by $5 \%$ level of different flour mixed packaged in HDPE at room temperature had initial score of 8.20 which further decreased to $8.100,7.980$ and 7.762 after 30, 60 and 90 days of storage period, respectively. However, mostly samples stored in HDPE were acceptable upto 90 days. The mixed flour of $7.5 \%$ level based biscuits packaged into HDPE at the room temperature was also acceptable at 90 days, because $7.5 \%$ level biscuits contain more protein and deterioration by microbiological changes.

From Table 2, it is explicit that the effect of composition of different levels of flour mixed ratio with wheat flours and stored in different HDPE at room temperature and storage period on overall acceptability score were found significant. From present investigation, it was concluded that $5 \%$ mixed flour based biscuits were found to be better overall acceptability than those of other ratios and followed by the ratio of $2.5 \%, 7.5 \%$ and wheat flour biscuits, packaged in HDPE, respectively. 
Rajmani Prajapati, Suresh Chandra and Samsher

Table 1: Effect on composition of different flours on the physico-chemical quality of biscuits

\begin{tabular}{|l|c|c|c|c|c|c|}
\hline Sample (Biscuits) & $\begin{array}{c}\text { Ash content } \\
(\%)\end{array}$ & $\begin{array}{c}\text { M.C. } \\
(\%)\end{array}$ & Protein & O.D. & Acidity & pH \\
\hline $\begin{array}{l}\text { Wheat flour } \mathrm{W}_{100} \\
\text { (Control) }\end{array}$ & $1.1827 \pm 0.0393$ & $2.703 \pm 0.1205$ & $4.98 \pm 0.056$ & $0.186 \pm 0.001$ & $0.1856 \pm 0.0056$ & $6.50 \pm 0.0076$ \\
\hline $\begin{array}{l}\mathrm{W}_{90} \mathrm{M}_{2.5} \mathrm{~B}_{2.5} \mathrm{~S}_{2.5} \mathrm{~J} \\
2.5\end{array}$ & $1.489 \pm 0.0402$ & $2.757 \pm 0.0585$ & $5.65 \pm 0.043$ & $0.192 \pm 0.003$ & $0.1365 \pm 0.0096$ & $6.65 \pm 0.0354$ \\
\hline $\mathrm{W}_{80} \mathrm{M}_{5} \mathrm{~B}_{5} \mathrm{~S}_{5} \mathrm{~J}_{5}$ & $1.643 \pm 0.0212$ & $2.873 \pm 0.0971$ & $6.74 \pm 0.039$ & $0.195 \pm 0.002$ & $0.1004 \pm 0.0143$ & $6.80 \pm 0.0237$ \\
\hline $\mathrm{W}_{70} \mathrm{M}_{7.5} \mathrm{~B}_{7.5} \mathrm{~S}_{7.5} \mathrm{~J}_{7.5}$ & $1.9423 \pm 0.0493$ & $2.923 \pm 0.1069$ & $7.23 \pm 0.004$ & $0.204 \pm 0.002$ & $0.0879 \pm 0.0867$ & $6.90 \pm 0.0192$ \\
\hline $\mathrm{CD}(\mathrm{p}<0.05)$ & 0.057 & $\mathrm{NS}$ & 1.021 & 0.0014 & 0.0543 & 0.130 \\
\hline $\mathrm{SEm} \pm$ & 0.016 & 0.056 & 0.037 & 0.0052 & 0.0632 & 0.0163 \\
\hline
\end{tabular}

Table 2: Effect on composition of different flours on the overall quality of biscuits during storage

\begin{tabular}{|l|c|c|c|l|}
\hline \multirow{2}{*}{ Biscuits samples } & \multicolumn{4}{|c|}{ Storage Period (days) } \\
\cline { 2 - 5 } & Fresh & 30 Days & 60 Days & 90 Days \\
\hline $\mathrm{W}_{100}($ Control) & $7.25 \pm 0.66$ & $7.075 \pm 0.61$ & $6.762 \pm 0.77$ & $6.427 \pm 0.85$ \\
\hline $\mathrm{W}_{90} \mathrm{M}_{2.5} \mathrm{~B}_{2.5} \mathrm{~S}_{2.5} \mathrm{~J}_{2.5}$ & $7.83 \pm 0.64$ & $7.747 \pm 0.64$ & $7.482 \pm 0.74$ & $7.292 \pm 0.81$ \\
\hline $\mathrm{W}_{80} \mathrm{M}_{5} \mathrm{~B}_{5} \mathrm{~S}_{5} \mathrm{~J}_{5}$ & $8.20 \pm 0.62$ & $8.100 \pm 0.63$ & $7.980 \pm 0.72$ & $7.762 \pm 0.79$ \\
\hline $\mathrm{W}_{70} \mathrm{M}_{7.5} \mathrm{~B}_{7.5} \mathrm{~S}_{7.5} \mathrm{~J}_{7.5}$ & $7.21 \pm 0.71$ & $7.175 \pm 0.05$ & $6.887 \pm 0.82$ & $6.612 \pm 0.87$ \\
\hline
\end{tabular}

\section{Conclusion}

Experiments were conducted to develop the mixed flours. Wheat flour was incorporated with mushroom flour, black gram flour, soya flour and jowar (sorghum) flour blends in ratios of $\quad 100: 0: 0: 0: 0, \quad 90: 2.5: 2.5: 2.5: 2.5$, 80:5.0:5.0:5.0:5.0 and 70:7.5:7.5:7.5:7.5, respectively. Wheat flour of the ratio of 100:0:0:0:0 was considered as control. Prepared biscuits were packaged in HDPE stored at room temperature upto 90 days and to examine overall sensory quality attributes of biscuits. From present investigation, it was concluded that 5\% mixed flour based biscuits were found to be better overall acceptability than those of other ratios.

\section{References}

Alim, M.A., Shams-Ud-Din M., (2003). The effects of cassava flour on the baking properties of sweet biscuits. Bangladesh Journal of Agricultural Engineering, 12 (1\&2): 69-80.

Anjum, F.A., I. Ahmad, M.S. Butt, M.A. Sheikh and I. Pasha. (2005). Amino acid composition of spring wheat's and losses of lysine during chapatti baking. Journal of Food Composition \& Analysis, 18:523-532.
Chandra, S., Samsher., Kumar, P., Vaishali and Kumari, D. (2015). Effect of incorporation of rice, potato and mung flour on the physical properties of composite flour biscuits. South Asian Journal of Food Technology and Environment, 1(1): 64-74.

Egan, H., Kirk R.S., Sawyer R., (1981). Pearson's chemical analysis of food 8th Edt. Churchill Livingstone, Medical division of Longman group Ltd. Great Britain. p. 591.

Eggum B.O., Beame R.M. (1983). The nutritive value of seed proteins. Seed protein biochem., Gen. nutr. value p. 499-53.

Kabirullah, M., Rukonuddin, A. Khan, S.A., Mosharef, H., Mojibur, R.A.K.M., Azizul, M.I.K. and Moazzam, M.H. (1995). Analysis of Nutrients of Bangladeshi Processed Foods. Part I-Different types of biscuits. Bangladesh J. of Scientific and Industrial Research, 30 (1): 121.

Laguna Laura, Salvador Ana, Sanz Teresa, Fiszman Susana M., (2011). Performance of a resistant starch rich ingredient in the baking and eating quality of short-dough biscuits. LWT - Food Science and Technology, 44:737-746.

Mishra, P., Usha, M. S. and Singh, S. (1991). Bengal gram flour-Wheat flour blends: 
chemical, archeological and baking characters. Journal of Food Science and Technology, 28: 89-97.

Ranganna, S. (2001). Handbook of analysis and quality control for fruit and vegetable products, Tata McGraw Hill Publishing Co. Ltd., New Delhi.

Senthil Amudha, Ravi R., Bhat K.K., Seethalakshmi M.K., (2002). Studies on the quality of fried snacks based on blends of wheat flour and soya flour, Food Quality and Preference, 13: 267-273.

$\begin{array}{ll}\text { Received } & \text { : January, 2019 } \\ \text { Revised } & \text { : March, 2019 } \\ \text { Published } & \text { : June, 2019 }\end{array}$

